UDC 94 (477)"1939/1945":34

\author{
Rekotov Petro, \\ Candidate of Juridical Sciencas, \\ Docent, Associate Professor at the \\ Department of the Engineering Institute \\ Zaporizhzhia National University, \\ Zaporizhzhia, Ukraine
}

\title{
NORMATIVE BASES OF PUBLIC BOARDS OF INQUIRY CRIMES IN THE TERRITORY LIBERATED FROM HITLER'S INVADERS
}

In the article normative bases of the public broards of establishing and investigating crimes of Hitler's invaders and their accomplices and damage caused by them to citizens, collective farms, public organizations, state enterprises of the USSR are considered. Their investigations by the Emergency State Commission (ESC) and the Ukrainian Republican Commission (URC) made it possible to punish Hitler's criminals for war crimes in the occupied territory of the USSR, in particular the Ukrainian SSR, and was of great importance for the result of the war and the development of events in the post-war period.

The publication raises the problems of responsibility for crimes committed in the occupied territories, and currently is relevant from the point of view of the need to take into account historical legal experience for modern and future legal practice in our state and the evolution of humanitarian law.

There is a growing view that the commission of war crimes is embedded in the nature of the war, but the crimes of Hitlerites in their scope and manifestations exceeded the known examples from the history of wars, and this, accordingly, led to the need to create a mechanism to combat the atrocities of invaders, an important organizing element of which was the emergency state commission to establish and investigate the crimes of Hitlerite invaders.

Material of the article confirms that the establishment of commissions was preceded by a number of diplomatic steps of the USSR and representatives of the 
governments of Belgium, Czechoslovakia, France, Greece, Luxembourg, the Netherlands, Norway, Poland and Yugoslavia (i.e. the countries occupied by Germany), the activities of law enforcement agencies, in particular archival institutions under the jurisdiction of the NKVD, as well as illustrated by the participation of law enforcement agencies in this process.

Based on documentary evidence, it is reasonable that the state emergency commissions were a centralized system of bodies for the establishment and investigation of the atrocities of the German invaders and their accomplices and the damage caused by them, were established and acted on the basis of the relevant Decree of the Presidium of the Supreme Soviet of the USSR (the commission was charged with collecting documentary data, checking them and preparing all the materials on the atrocities of Hitler's criminals and material damage, determining the general powers and approval of the personnel) and resolutions of the USSR SNC, guided by the requirements of the Regulations on the Extraordinary State Commission and instructions, determined the tasks of the drug addicts of the USSR and the Union republics, the forms and methods of their work.

The peculiarities of the conditions for the establishment of commissions are shown, in particular, the formation of regional and district commissions to establish and investigate the facts of crimes took place as the territory of the USSR and the Ukrainian SSR was liberated. Their composition was determined by the Regulations of the NDC.

The author provides evidence confirming the fact that he is interested in the experience of normative support of the work of the Extraordinary State Commissions with a view to its use by the states that suffered from Hitler's occupation (France, Yugoslavia).

Keywords: Emergency State Commission, Ukrainian Republican Commission, NKVD, decrees, resolutions, regulations, instructions.

\section{REFERENCES}

1. Morozov V., Kolotsei M. (2015). Ugolovnoye presledovaniye natsistskikh prestupnikov za zlodeianiia, sovershennye na territorii Belarusi. "Criminal prosecution 
of Nazi criminals for atrocities committed in Belarus". Law and order. No. 4. P. 55-60. [in Russian].

2. Morin A.Ye. (2004). Uholovnoie presledovaniie natsistskikh prestupnikov. Rabota sovetskikh pravookhranitelnykh orhanov po ustanovleniiu i rassledovaniiu voiennykh prestuplenii protiv mira i chelovechnosti. "The prosecution of Nazi criminals. The work of Soviet law enforcement agencies to establish and investigate war crimes against peace and humanity". Soviet and German prisoners of war during the Second World War. Dresden-Minsk. 512 p. [in Russian].

3. Yepifanov A.Ye. (2019). Stalinhradskiie orhany vnutrennikh del v borbe $\mathrm{s}$ gitlerovskimi voyennymi prestupnikami (1942-1943 gg.). "The Stalingrad internal affairs bodies in the fight against Nazi war criminals (1942-1943)". Historia Provinciae - Journal of Regional History. 2019. Vol. 3. No. 1. P. 318-370. [in Russian].

4. Maksymchuk Ye. (2007). Diialnist Derzhavnykh komisii z rozsliduvannia zlochyniv natsystiv na terytorii Ukrainy (1941-1951 rr.): typovo-vydovyi sklad ta informatsiinyi potentsial dzherelnoho kompleksu. "Activities of the State Commissions for the Investigation of Nazi Crime in Ukraine (1941-1951): Typical Species Composition and Information Potential of the Source Complex": author. diss. Cand. Histor. Sciences. K. 20 p. [in Ukrainian].

5. Haidashev A.V. (2013). Chrezvychaynaya gosudarstvennaya komissiya po rassledovaniyu zlodieianii nemetsko-fashistskikh zakhvatchikov i ikh soobshchnikov v period Velikoi Otechestvennoi voyny (na materialakh Stalinhradskoi oblasti). "Extraordinary state commission to investigate the atrocities of the Nazi invaders and their accomplices during the Great Patriotic War (based on materials from the Stalingrad region)". Bulletin of Chelyabinsk State University. No. 6 (297). Istoriia. Vol. 54. P. 53-56. [in Russian].

6. Sbornik zakonov SSSR i ukazov Prezidiuma Verkhovnoho Soveta SSSR. "Collection of USSR laws and decrees of the Presidium of the Supreme Soviet of the USSR. 1938 - July 1956" / under the editorship of Ph.D. Mandelstam Yu.I. Moscow: State Publishing House of Legal Literature, 1956. 535 p. [in Russian].

7. Yepifanov A.Ye.(2017). Organizatsionnye i pravovye osnovy deiatelnosti komissii po ustanovleniiu i rassledovaniiu gitlerovskikh zlodeianii. "Organizational 
and legal basis for the activities of commissions to identify and investigate Hitler's crimes". LEGAL CONCEPT = Legal Paradigm. No. 4. P. 54-61. [in Russian].

8. Mukharovska A.O. (2015). Diialnist derzhavnykh komisii shchodo obliku zbytkiv, zapodiianykh natsystskymy zaharbnykamy hospodarstvu i naselenniu u Volynskii ta Rovenskii oblastiakh. "Activities of state commissions for accounting of losses caused by Nazi invaders to the economy and population in Volyn and Rivne regions": diss. ... Cand. ist. Sciences: 07.00.01. State Committee of Archives of Ukraine. Lutsk. 337 pages.: ill. URL: https://ra.eenu.edu.ua/wpcontent/uploads/2018/06/Muharovska-A.O.-dysertatsiya.pdf. (date of application: 1.10.2019). [in Ukrainian].

9. Myshchak I. (2004). Dialnist arkhivnykh ustanov Ukrainy v roky Velykoi Vitchyznwanoi viiny. "Activities of the archival institutions of Ukraine during the Great Patriotic War". History of Ukraine. Little known names, events, facts: coll. articles. No. 26. P. 96-108. [in Ukrainian].

10. Zhyhlo V. (2008). Dzhereloznavchi doslidzhennia ta vydannia dokumentiv zony viiskovoho upravlinnia vermakhtu u period 1942-1991 rokiv. "Source research and publication of documents of the Wehrmacht military management zone in the period 1942-1991". Scientific notes. Collected Works of Young Scientists and Graduate Students. P. 449-461. [in Ukrainian].

11. Maksymchuk Ye. (2006). Ohliad fondu Ukrainskoi respublikanskoi komisii z obliku zbytkiv i zlochyniv, zapodiianykh nimetsko-fashystskymy zaharbnykamy. "Review of the Fund of the Ukrainian Republican Commission for Accounting for Losses and Crimes Caused by Nazi Invaders". Studios from the archive. cases and documentary science. T. 14. P. 92-94. [in Ukrainian].

12. Tsyt. po: Ukraina pid natsystskoiu okupatsiieiu: spaleni sela (1941-1944 rr.): anotovanyi pokazhchyk. "Quotation. by: Ukraine under Nazi occupation: burnt villages (1941-1944): annotated index / ed. V.F. Soldier; authored by: Butko S.V. etc. K.: State Enterprise "Priorytety" State Enterprise, 2012. 362 p. [in Ukrainian].

13. Sebta T.M. (2010). Dokumentalni fondy nimetskoi okupatsiinoi vlady $1941-$ 1944 rr. u derzhavnykh arkhivakh Ukrainy: analiz informatsiinoho potentsialu. "Documentary Foundations of the German Occupation Authority of 1941-1944 in the 
State Archives of Ukraine: Analysis of Information Potential”. Archives of Ukraine. 2010. No. 2 (268). Pp. 23-46. URL: http://nbuv.gov.ua/UJRN/ay_2010_2_3. (date of application: 1.10.2019). [in Ukrainian]. 